\title{
The effect of calorie to protein ratio of practical diets on performance and carcass quality of broiler chickens
}

\author{
Tion M.A., M.T.Orga and I.A.Adeka. \\ Teparment of Animal Production, University of Agriculture, Makurdi, Benue State, Nigeria.
}

\begin{abstract}
One hundred and ninety two sexed broiler finisher chickens were utilized in a completely randomized iesign to test the dietary effects of calorie: protein ratio on the performance and carcass quality of croilers reared to 63 days of age. Sixteen birds ( 8 males and 8 females) per pen and 48 per diet were zssigned at random to 12 homogenous pens, each measuring $3.5 \times 1.75 \mathrm{~m}^{2}$ in an open sided poultry nouse. Feed and water were offered ad libitum. At the end of the feeding trial, 2 birds of each sex (4 birds/pen and 12/diet), which had their weights close to the pen average, were selected for carcass evaluation. Processed birds had their abdominal and gizzard fats recovered and weighed. Results showed that calorie: protein ratio had no significant effect on all the performance traits measured. However, statistical analysis of mean values for feed intake and feed: gain ratio was close to attaining significant level at $P<0.05$. Carcass traits (final body weight, fat weight, and percentage fat) were however significantly $(P<0.05)$ affected by calorie: protein ratio. The study gives an indication that calorie: protein ratio as wide as $178: 1$ can be gainfully utilized in this country for finishing broilers to market weight $(>2.0 \mathrm{~kg}$ ) in 63 days.
\end{abstract}

Key words: Calorie: protein ratio, broiler finisher diets, performance, carcass traits.

\section{Introduction}

Formulated diets for broiler chickens are aimed at promoting rapid growth and improved feed conversion efficiency. Where success is reported in this area, the carcasses of broilers produced from many of the formulations are often criticized for producing high fat content alongside the fast growth rate. Excess fat in broilers is considered a waste product of processing which increases plant processing cost, through clean up operations. Several methods for reducing carcass and abdominal fat in broilers have been investigated by researchers. One of the methods is to vary the levels of calorie: protein $(\mathrm{C}: \mathrm{P})$ ratios of diets in such a way that will promote rapid growth rate while minimizing the amount of fat deposited in broilers so as to obtain acceptable carcasses.

Bartov et al (1974) studied the effect of calorie: protein ratio on broiler finishers. The ratio was wide enough to cause a significant effect on efficiency of feed utilization and carcass fat but did not affect growth rate significantly. Lipstein et al (1975) created different calorie: protein 
ratios ( 171 to $201: 1$ ) by reducing protein levels from $18.1 \%$ progressively to $15.7 \%$. Feed consumption was increased with successive widening of the ratios. Growth rate was not affected, but fat deposition increased when broilers werc fed such diets. Lipstein and Bornstein (1975) also showed that wider calorie: protein ratio increased feed intake, which they attributed to the low level of protein intake and excess energy intake, which increased fat deposition in broilers.

Olomu and Offiong (1980) created different calorie: protein ratios from diets differing in energy $(2800,3000,3200 \mathrm{Kcal} / \mathrm{Kg})$ and $(17,20$ and $23 \%$ ) crude protein. Feed intake did not vary significantly between the different dietary ratios. Baghel and Pradhan (1989) fed diets that differed in energy $(11.7,12.5$ and $13.4 \mathrm{MJ} / \mathrm{Kg})$ and protein levels $(200,220,230$ and $250 \mathrm{~g} / \mathrm{Kg})$ in the starter phase, $180,200,220$ and 240 in the grower phase and $160,180,190,2 \mathrm{J0g} / \mathrm{Kg}$ in the finisher phases respectively. They reported greater weight gain for broilers receiving low energy high protein (low calorie: protein ratio) during all phases of growth. Feed intake values were higher on these low calories: protein ratios. High ambient temperature $\left(45^{\circ} \mathrm{C}-54^{\circ} \mathrm{C}\right.$ maximum and $17^{\circ} \mathrm{C}-22^{\circ} \mathrm{C}$ minimum) did not prevent broilers from consuming large quantities of the low energy feed resulting in poor feed utilization. The wider calorie: protein ratio (high calorie, low protein diet) produced poor weight gain and the birds consumed significantly less feed. The authors explaincd that birds were unable to consume adequatc amount of nutrients other than energy and this resulted in low weight gain. Ngi (1999) reviewed that birds cat to satisfy their energy requirement and will reduce intake drastically once that nutrient is satisfied. Tion et al (2000) created dictary calorie: protein ratios of 126, 143, 153:1 in finishing broiler diets. They reported lack of significant effect of the ratios on feed intake, efficiency of feed utilization and growth rate but there was significant effect of these ratios on absolute fat values but not relative fat values.

The calorie: protein ratio for finisher dicts in temperate region (USA) is 160:1 (NRC 1994). Olomu (1995) suggested a narrower ratio (150:1) for tropical region. Ola and Adeogun (2001) suggested ratios of $133.3,140$ and 153.4:1 for the finisher rations. Janky et al (1976) reported that wider calorie; protein ratio produced significantly higher eviscerated and ready to cook yield than narrower ratio. Saxona and Pradhan (1978) reported that carcasses of broiler that were fed wide calorie: protein ratio diets (calorie: protein ration 170:1) had significantly higher fat value than those fed diets with calorie: protein ratio of 145:1. The objective of the trail was to study the effects of calorie: protein ratios of broiler finisher diets on performance and carcass quality of broilers reared to 63 days of age.

\section{Materials and Methods}

From a group of 240 broiler chicks, 28 days of age, that were brooded for the purpose of this study, it was possible to identify and select 192 chicks that were made up of equal males and females using comb and wattle development. Deliberate efforts were made to minimize weight variations among the selected chicks. The selected chicks were assigned to 12 homogenous pens measuring $3.5 \times 1.75 \mathrm{~m}^{2}$. Each pen had 8 males and 8 females. House construction was an open sided poultry house. Four dietary treatments were formulated in the finishing phase using maize and soyabean, which were manipulated to achieve the required calorie: protein ratio. Diet 1 contained $3200 \mathrm{Kcal} / \mathrm{Kg} \mathrm{ME}$ and $18 \% \mathrm{CP}$ to achieve a $\mathrm{C}: \mathrm{P}$ ratio of $178: 1$; diet 2 contained $3200 \mathrm{Kcal} / \mathrm{Kg} \mathrm{ME}$ and $20 \% \mathrm{CP}$ to achieve a C: $P$ ratio of $160: \mathrm{I}$; diet 3 contained $3000 \mathrm{Kcal} / \mathrm{Kg}$ $\mathrm{ME}$ and $20 \% \mathrm{CP}$ to achieve a $\mathrm{C}$ : P ratio of 
$150: 1$, and diet 4 contained $2800 \mathrm{Kcal} / \mathrm{Kg} \mathrm{ME}$ and 20\% CP to achieve a C: P ratio of 140:1 (Table 1). Each diet was assigned to 3 replicate pens. Feed and water were not restricted. Birds were weighed individually at the start of the study and weekly thereafter.

The birds remaining from the selection process were reared separately. When they were 6 weeks old, 24 birds were selected from the lot and assigned at random to 12 carefully constructed homogenous cages each of which measured 60 $\times 35 \times 40 \mathrm{~cm}^{3}$ such that each cage accommodated two birds. A seven day adjustment period was allowed the caged birds. At the end of the adjustment period birds were fasted for 24 hours to reduce the content of the gastro-intestinal tract. The 4 test dicts were assigned at random to the cages such that each diet was assigned to 3 cages. Faecal collection started after 72 hours on experimented diets and lasted for 4 days. Faeces were received on re-enforced polythene sheets which were tied just underneath each cage. Feed and water were offcred ad libitum. The amount of feed consumed each day was determined and recorded. Faecal droppings were collected at

Table 1:

The composition of the experimental diets

\begin{tabular}{lcccc}
\hline & \multicolumn{3}{c}{ Calorie: protein ratio } & \\
\cline { 2 - 4 } Feedstuffs & $\mathbf{1 7 8 : 1}$ & $\mathbf{1 6 0 : 1}$ & $\mathbf{5 0 : 1}$ & $\mathbf{1 4 0 : \mathbf { 1 }}$ \\
\hline Full fat soyabean (cooked) & 7.87 & 40.00 & 42.80 & 45.00 \\
Maize & 45.00 & 55.00 & 46.30 & 37.50 \\
Cassava flour & 7.10 & - & - & 1.00 \\
Palm oil (red) & 2.50 & - & - & - \\
Bonc mcal & 3.90 & 3.70 & 3.80 & 3.80 \\
Methionine (DL) & 0.22 & 0.19 & 0.20 & 0.25 \\
Salt & 0.25 & 0.25 & 0.25 & 0.25 \\
* Vitamin/mineral premix & 0.25 & 0.25 & 0.25 & 0.25 \\
Sand & 0.40 & - & 0.40 & 2.00 \\
Rice offal & 2.51 & 0.61 & 6.00 & 10.00 \\
Total & 100.00 & 100.00 & 100.00 & 100.00 \\
& & & & \\
Calculated Analysis & & & & \\
Crude protein (\%) & 18.00 & 20.00 & 20.00 & 20.00 \\
Energy (KCal/Kg ME) & 3200.00 & 3200.00 & 3000.00 & 2800.00 \\
Caiorie: Protein (ratio) & $178: 1$ & $160: 1$ & $150: 1$ & $140: 1$ \\
Calcium (\%) & 1.50 & 1.44 & 1.48 & 1.48 \\
Phosphorus (\%) & 1.02 & 1.08 & 1.07 & 1.05 \\
Calcium: Phosphorous (ratio) & $1.47: 1$ & $1.33: 1$ & $1.38: 1$ & $1.41: 1$ \\
Crude fiber (\%) & 3.90 & 3.60 & 5.35 & 6.60 \\
\hline
\end{tabular}

*Agricare Premix, (Ptizer): sumpled the following additional micronutrients: Vitamins A, 10,000 iu, D, 2,000 iu,

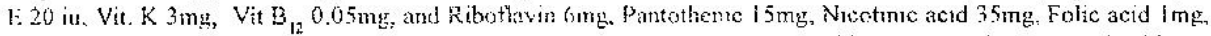

chlorine Chloricte forme and $\mathrm{Se} 015 \mathrm{mg}, \mathrm{Ca} 12 \mathrm{mg}, \mathrm{Mn} 55 \mathrm{mg}, \mathrm{Fo} 55 \mathrm{mg}$, antioxidant (LTH) $70 \mathrm{mg}$, an anti caking 
8:00hours and weighed immediately each day. Dropping were spread out on a wire netting screen cabinet and dried in the sun for 48 hours and dried further, at $60^{\circ} \mathrm{C}$ for 24 hours as partial dried faeces. Dried faeces were equilibrated for 24 hours in the laboratory. Feed and faecal samples were ground in a Wiley mill using a $2 \mathrm{~cm}$ screen, composited and stored in air-tight jars for later analysis. Samples of dietary treatments and faeces were analysed for dry matter (DM), crude protein (CP) ether-extract (EE) and crude fiber (CF) according to procedures described by AOAC (1980). Energy determination of both feeds and faeces were carried out using the Parr Adiabatic Bomb calorimeter according to procedures described by Parr Instrument Company (1966). Metabolizable energy values of diets were estimated from the differences between gross energy values of feeds and faeces of each dict and adjusted to dry mattcr basis. (Table 2)

At the end of the feeding trial, 2 birds of each sex ( 4 per pen and 12 per diet), which had their weights close to the pen average, were selected for carcass evaluation. Each bird was identified by wing band number, and fasted overnight. Weights were taken the next day and birds were slaughtered, dipped in hot water $\left(65^{\circ} \mathrm{C}\right)$ for 30 seconds and de-feathered manually. Evisceration was carried out and abdominal and gizzard fa: were recovered and wrapped in duplicating pape: which had the corresponding identification number of the bird already written. Wrapped fa: was tied up in small polythene bag and packed in ice. The remaining carcass was weighed and refrigerated. After the operation, the chilled fats were stored in deep freezer overnight until the next day when the gizzard fat was removed with the aid of a table knife. Fat was weighed using digital weighing balance. Data collected were analysed statistically using the completely randomized design procedures and mean separation where applicable was carried out using the Duncan New Multiple Range Test as outlined by Steel and Torrie (1980).

\section{Results and Discussion}

The result of the effect of calorie: protein (C:P) ratio on performance traits is presented in Table 3 . The result showed that $C: P$ ratio had no significant effect on all the performance traits monitored. Feed intake of birds that were fed diet 4 (C: P 140:1) was higher, although not significantly different from others. This was thought to be due to the lower energy level of that diet. Baghel and Pradhan (1989) fed broiler

Table 2. The proximate composition of experimental diets.

\begin{tabular}{lllll}
\hline Parameters & \multicolumn{4}{c}{ Calorie: Protein ratio } \\
\hline Nutrient Composition* & 1781 & $160: 1$ & $150: 1$ & $140: 1$ \\
Crude Protein (CP) \% & 18.90 & 20.87 & 21.06 & 20.76 \\
Ether Extract (EE) \% & 11.50 & 9.56 & 10.29 & 10.77 \\
Crude Fiber (CF) \% & 4.21 & 3.81 & 5.68 & 7.25 \\
Ash \% & 7.54 & 6.31 & 7.32 & 10.44 \\
Energy (Kcal/kg ME) & 3318.61 & 3290.24 & 3126.46 & 2900.85 \\
\hline
\end{tabular}

- Values are expressed on dry matter basis 
Table 3: The effect of calorie: protein ratio of diets on performance of broiler chickens at finisher phase

\begin{tabular}{|c|c|c|c|c|c|}
\hline \multirow[b]{2}{*}{ Parameters } & \multicolumn{4}{|c|}{ Calorie: Protein Ratio } & \multirow[b]{2}{*}{ SEM } \\
\hline & 178: 1 & 160: 1 & 50: 1 & 140: 1 & \\
\hline Feed intake $(\mathrm{g}) / \mathrm{bird} /$ day & 171 & 167 & 175 & 195 & 0.33 \\
\hline Weight gain $(\mathrm{g})$ & 75 & 74 & 69 & 72 & 0.05 \\
\hline Feed: gain & 2.28 & 2.25 & 2.53 & 2.7 & 0.11 \\
\hline Feed: cost/Kg gain $(\mathrm{A})$ & 81.36 & 78.65 & 86.23 & 91.24 & - \\
\hline$(\$)$ & 0.58 & 0.56 & 0.62 & 0.65 & - \\
\hline
\end{tabular}

Mean values within a row do not differ $(\mathrm{P}>0.05)$

$\mathrm{SEM}=$ Standard Frror of Means

finisher diets with varying energy levels (11.7, 12.5 , and $13.4 \mathrm{MJ} / \mathrm{Kg}$ ). Feed intake value was higher on the low energy diet. Olomu (1979) suggested metabolizable energy valucs of 2800 or $3000 \mathrm{Kcal} / \mathrm{Kg}$ for broilers. However, Olomu (1995) revised the energy requirement upwards by dropping $2800 \mathrm{Kcal} / \mathrm{Kg}$ and retaining only the $3000 \mathrm{KCal} / \mathrm{Kg} \mathrm{MF}$. Probably the lower energy level $(2800 \mathrm{Kcal} / \mathrm{Kg} \mathrm{ME})$ was not able to support optimal requirement of broilers. It appears from the result obtained from this study that energy level of $2800 \mathrm{KCal} / \mathrm{Kg} \mathrm{ME}$ for broiler finisher chickens was slightly inadequate to meet the birds' optimal requirements. Ngi (1999) reviewed that birds eat to satisfy their energy requirement before reducing intake. As a result of higher feed intake of birds fed the low energy diet, the feed cost per kilogram gain was higher among the tested diets. Although, weight gain was not generally significantly affected by calorie: protein ratio, the high energy low protein diet (diet I, C: P 178:1) produced broilers that wcre consistently heavier than the other groups over the five week weighing period. Tion et al (2000) did not observe any significant effect of calorie: protein ratio of diet differing by 126,143 and 153:1 ratios on weight gain. Lipstein $e t$ al (1975) used calorie: protein ratio as wide as
201:1 and reported lack of significant response on weight gain. The feed conversion ratios obtained in this study was close to attaining significant level at $5 \%$. Diets 3 and 4 with narrower C: $P$ ratios ( 150 and 140:1) caused this effect. Baghel and Pradhan (1989) also observed this poorer feed conversion ratio on the low energy high protein diets.

Results of carcass traits are presented in Table 4. Weight of the birds selected for carcass traits on the basis of being close to the mean of the pen, differed significantly $(\mathrm{P}<0.05)$. This showed that although all the birds grew well for their age, diet 4 (C: P 140: 1) produced the least weight, which was significantly smaller than the other three dicts. It is believed that the procedure of selecting birds rather than the $\mathrm{C}$ : $\mathrm{P}$ ratio caused these significant differences. The New York dressed weight (whole chicken, less blood, feathers, intestine, gall bladder and oil sack) was significantly $(\mathrm{P}<0.01)$ influenced by $\mathrm{C}$ : $\mathrm{P}$ ratio, perhaps, through the selection process. Diet 1 (C: P 178:1) produced the highest mean value, which was not significantly different from diet 2 (C: $\mathrm{P} 160: 1$ ). The New York dressing percentage was not significantly $(P>0.05)$ different on all diets. Anonymous (1983) suggested a $92 \%$ yield 
Table 4: The effect of calorie: protein ratio of diets on carcass traits of broiler reared to 63 days of age

\begin{tabular}{lccccc}
\hline & \multicolumn{4}{c}{ Calorie: Protein Ratio } & \\
\cline { 2 - 5 } Carcass Traits & $\mathbf{1 7 8 : 1}$ & $\mathbf{1 6 0 : 1}$ & $\mathbf{5 0 : 1}$ & $\mathbf{1 4 0 : 1}$ & SEM \\
\hline Final body weight (Kg) & $2.66^{\mathrm{a}}$ & $2.58^{\mathrm{ab}}$ & $2.50^{\mathrm{b}}$ & $2.36^{\mathrm{c}}$ & 0.04 \\
New York Dressed weight $(\mathrm{kg})$ & $2.41^{\mathrm{a}}$ & $2.28^{\mathrm{ab}}$ & $2.21^{\mathrm{b}}$ & $2.15^{\mathrm{b}}$ & 0.05 \\
Dressed weight (Kg) & $2.03^{\mathrm{a}}$ & $1.93^{\mathrm{ab}}$ & $1.85^{\mathrm{b}}$ & $1.81^{\mathrm{b}}$ & 0.02 \\
New York Dressing \% & 90.43 & $\mathbf{8 8 . 5 5}$ & 88.50 & 91.18 & 1.61 \\
Dressing \% & $76.32^{\mathrm{a}}$ & $74.85^{\mathrm{b}}$ & $74.00^{\mathrm{c}}$ & $76.69^{\mathrm{a}}$ & 0.10 \\
Fat weight (g) & $63.47^{\mathrm{a}}$ & $55.04^{\mathrm{a}}$ & $39.90^{\mathrm{b}}$ & $31.37^{\mathrm{b}}$ & 4.58 \\
Fat \% (of body weight) & $2.41^{\mathrm{a}}$ & $2.14^{\mathrm{ab}}$ & $1.53^{\mathrm{bc}}$ & $1.35^{\mathrm{c}}$ & 0.21 \\
Wasted fat (N Value) & 25.39 & 22.02 & 15.96 & 12.55 & - \\
\multicolumn{1}{c}{ (\$ Value) } & 0.18 & 0.16 & 0.11 & 0.09 & - \\
\hline
\end{tabular}

$a, b, c$ Mean values within a row with same or without superscript do not differ $(\mathrm{P}>0.05)$

SEM $=$ Standard Error of Means

on New York dressed (remover of just feathers and blood) broilers as a rcasonable estimate for developing countries. Mean values obtained in this study $(88.5 \%$ to $91.18 \%)$ are in general agreement with the suggested value since the intestine, gall bladder, and oil sack were not included in determining the New York dressed percentages in this study. Dressed weight (empty carcass with neck) was significantly $(P<0.01)$ influenced by the different diets (calorie: protein ratios). Diet 1 (C: $P$ 178: 1) produced the heaviest weight but was not significantly $(\mathrm{P}>0.05)$ different from diet 2 (C: P 160: 1). The dressing percentage for carcass weight differed significantly $(P<0.01)$ among the four diets.

Anonymous (1983) suggested that the percentage dressed yield could vary from $75 \%$ to $95 \%$ depending on the amount of water which may be picked up and retained during the chilling process, and whether the head and shanks are left on (as is the case in most developing countries), as well as the lungs, abdominal fa: and oil sack. The dressing percentage values reported in this study consisted of carcass with: neck and lungs. The abdominal fat and viscera: organs were not part of carcass from which the dressing percentages were calculated anc analysed. The amount of water, which could have been picked up during refrigeration was not likely because, the carcasses were sealed up in a polyethene bag before storing in the refrigerator. Mean values for dressing percentages are therefore in agreement with the range (75\% to $95 \%$ ) reported by Anonymous (1983). Dressed weight represent the absolute value of salable meat and were generally high for all diets. Since cven aftcr abdominal fat removal from carcasses. the widest C: $\mathrm{P}$ ratio diet (diet 1) produced the highest absolute mean value, it gave an indication that, finishing broiler can perform well on a $\mathrm{C}: \mathrm{P}$ ratio of as wide as 178: 1 
Absolute mean value for fat resulted in significant difference $(\mathrm{P}<0.05)$ between the lower C: $P$ ratios (150 and 140:1) and higher C: P ratios (178 and 160:1). Bartov et al (1974) reported that diets varying only marginally in C: $\mathrm{P}$ ratio caused significant effect on carcass fat. Lipstein et al (1975) showed that once the C: P ratio of the diets was widened to more than 164:1, carcass fat deposition became apparent. Saxona and Pradhan (1978) reported that carcasses of broilers fed diets with C: P ratio of 170:1 had significantly more fat than those fed the $145: 1 \mathrm{C}$; $\mathrm{P}$ ratio diet. Relative mean values for fat also resulted in significant differences among the various C: $\mathrm{P}$ ratios used. As expected, the narrower C: $P$ ratios (150:1 and 140:1) produced leaner carcass with smaller fat percentages.

The higher mean values of salable meat obtained from the wider calorie: protein ratio (178 and 160:1) was attributed to greater subcutaneous and tissue fats, which form marbling of the muscle tissue and is referred to as carcass fat. This fat constitutes part of the sensory quality of meat and is accepted as normal part of salable carcass. Dressed carcass weights from diets with narrower calorie: protein ratios (150 and 140:1) suggested for feeding finishing broilers in this country were smaller, but the amount of feed it took to produce such carcasses cost more than the feeds with wider ratios (178 and 160:1). Abdominal fat of broilers obviously constitute part of the live broilers and influence their price determination. The lower feed cost per kilogram gain of wider calorie: protein ratio (178 and 160:1) diets means that more money will be obtained from sale of broilers fed such diets. Anomymous (1983) estimated that percent abdominal fat of finished broilers should be $2 \%$. The wider calorie: protein ratio (178 and 160:1) diets produced finished broilers with percent abdominal fat only slightly over this value. Therefore, broiler finisher diets with calorie: protein ratio wider than the presently suggested ratios (150 or 140:1) can also be utilized gainfully for purpose of optimum production and economic returns in this country.

\section{Conclusion}

From the results of this study, the energy level of broiler finisher diet can be stepped up to 3200 $\mathrm{KCal} / \mathrm{Kg}$ ME while the crude protein level can be stepped down to $18 \%$, thereby creating a C: $\mathrm{P}$ ratio of 178: 1. This will enhance good performance and carcass yield, and bring about good economic returns on the farmer's investment.

\section{Reference}

Anonymous (1983): Appraising poultry enterprises for profitability. A manual for potential investors. World Bank Technical Paper. No 10, Washington D. C

AOAC (1980): Official methods of analysis, $13^{\text {th }}$ ed. Association of Official Analytical Chemists, Washington, D. C.

Bartov, I., Bornstein and Lipstein, B. (1975): Effect of calorie to protein ratio on the degree of fatness in broilers fed on practical diets. Brit. Poult. Sci. 15: $107-117$

Baghel, R. P. S. and Pradhan, K. (1989):

Energy, protein and limiting amino acid requirement of broilers at high ambient temperature. Brit. Poult. Sci. 30: $295-304$

Janky, D. M.; Riley, P. K., Harms, R. H. (1976): The effect of dietary energy level on dressing percentage of broilers. Poult. Sci. 56: $2388-2390$ 
Lipstein, B., Bornstein and Bartov, I. (1975): Effect of protein concentrations and amino acid supplementations in broiler finisher diets on fat deposition in the carcass. Brit. Poult. Sci. 16: 627-635.

Lipstein, B. and Bornstein (1975): Special additions of methionine and lysine as practical feedstuffs for protein in finisher diets. Brit. Poult. Sci. 16: 627635 .

Ngi, J. (1999): The effect of crumbs versus all mash broiler starter feeds on broilcr chick performance. B. Agric project, Universily of Agriculture, Makurdi.

N. R. C. (1994): Nutrient requirements of poultry. $9^{\text {th }}$ revised edition, National Academy of Science, Washington, D. C

Ola, S. I. and Adeogun, I. O. (2001):

Essential information for effective poultry farming. In: Improving poultry feed supply and litter management. Pp. $43-50$. Proc. of workshop organized by World's Poultry Sci. Association, Nigerian Branch, ed. Matanmi, I. O., Ola, S. I. and Adeogun, I. O.

Olomu, J. M (1979) - Poultry nutrition research, its contributions to National Poultry Industry. 1, Nutrient requirements, nutrient sources, nutrient content of feed ingredients. In: Poultry Production in Nigeria, Pp. 241 -268 NAPRI, Shika, A. B. U., Zaria.
Olomu, J. M., and Offiong, S. A., (1980): The effect of different protein and energy levels and time of change from starter to finisher ration on performance of broiler chickens in the tropics. Poult. Sci. 59: 828.

Olomu, J. M. (1995): Nutrient requirement of broiler chickens as percentages or as milligrams or units per kilogram dict In: Monogastric Animal Nutrition, Principles and Practice Pp. 70. Jachem Publication.

Parr Instrument Company (1966): Oxygen Bomb Calorimetry and Combustion Methods. Technical Manual No. 130 Parr Instrument Company, Molin Illinois

Saxona, V. P., and Pradhan, K. (1978): Carcass composition of broilers on maize and sorghum diets at various levels of energy and protein in summer months. Haryana Agric. Univ. J. Res. 8: $282-290$.

Steel, R. G. D. and Torrie, J. H. (1980): Principles and Procedures of Statistics. A Biometrical Approach. $2^{\text {nd }}$ ed. McGraw Hill Book Co. Inc., New York.

Tion, M. A., Adeka, I. A. and Brilers, C. O (2000): The effect of sex, energy and protein diets on growth rate and carcass traits of broiler chickens. Proc. $5^{\text {th }}$ Ann. Conf. Of ASAN: $5: 3-5$.

(Received 26 March 2004; Accepted 23 December 2004). 